NASA/TM-2003-211999

\title{
Experimental Results From a 2kW Brayton Power Conversion Unit
}

David Hervol

Analex Corporation, Brook Park, Ohio

Lee Mason and Arthur Birchenough

Glenn Research Center, Cleveland, Ohio 
Since its founding, NASA has been dedicated to the advancement of aeronautics and space science. The NASA Scientific and Technical Information (STI) Program Office plays a key part in helping NASA maintain this important role.

The NASA STI Program Office is operated by Langley Research Center, the Lead Center for NASA's scientific and technical information. The NASA STI Program Office provides access to the NASA STI Database, the largest collection of aeronautical and space science STI in the world. The Program Office is also NASA's institutional mechanism for disseminating the results of its research and development activities. These results are published by NASA in the NASA STI Report Series, which includes the following report types:

- $\quad$ TECHNICAL PUBLICATION. Reports of completed research or a major significant phase of research that present the results of NASA programs and include extensive data or theoretical analysis. Includes compilations of significant scientific and technical data and information deemed to be of continuing reference value. NASA's counterpart of peerreviewed formal professional papers but has less stringent limitations on manuscript length and extent of graphic presentations.

- TECHNICAL MEMORANDUM. Scientific and technical findings that are preliminary or of specialized interest, e.g., quick release reports, working papers, and bibliographies that contain minimal annotation. Does not contain extensive analysis.

- CONTRACTOR REPORT. Scientific and technical findings by NASA-sponsored contractors and grantees.
- CONFERENCE PUBLICATION. Collected papers from scientific and technical conferences, symposia, seminars, or other meetings sponsored or cosponsored by NASA.

- SPECIAL PUBLICATION. Scientific, technical, or historical information from NASA programs, projects, and missions, often concerned with subjects having substantial public interest.

- TECHNICAL TRANSLATION. Englishlanguage translations of foreign scientific and technical material pertinent to NASA's mission.

Specialized services that complement the STI Program Office's diverse offerings include creating custom thesauri, building customized databases, organizing and publishing research results ... even providing videos.

For more information about the NASA STI Program Office, see the following:

- Access the NASA STI Program Home Page at http://www.sti.nasa.gov

- E-mail your question via the Internet to help@sti.nasa.gov

- Fax your question to the NASA Access Help Desk at 301-621-0134

- Telephone the NASA Access Help Desk at 301-621-0390

- Write to:

NASA Access Help Desk

NASA Center for AeroSpace Information 7121 Standard Drive

Hanover, MD 21076 
NASA/TM-2003-211999

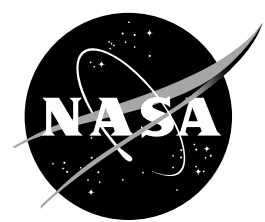

\title{
Experimental Results From a 2kW Brayton Power Conversion Unit
}

\author{
David Hervol \\ Analex Corporation, Brook Park, Ohio \\ Lee Mason and Arthur Birchenough \\ Glenn Research Center, Cleveland, Ohio
}

Prepared for the

Space Technology and Applications International Forum (STAIF-2003) cosponsored by the American Institute of Aeronautics and Astronautics and the University of New Mexico

Albuquerque, New Mexico, February 2-6, 2003

National Aeronautics and

Space Administration

Glenn Research Center 


\section{Acknowledgments}

The work described in this paper was performed by the staff of NASA Glenn Research Center at Lewis Field for the Office of Space Station (Code S) Program at NASA Headquarters.

This report is a formal draft or working paper, intended to solicit comments and ideas from a technical peer group.

This report contains preliminary findings, subject to revision as analysis proceeds.

This report is a preprint of a paper intended for presentation at a conference. Because of changes that may be made before formal publication, this preprint is made available with the understanding that it will not be cited or reproduced without the permission of the author.

Available from

NASA Center for Aerospace Information 7121 Standard Drive

Hanover, MD 21076
National Technical Information Service 5285 Port Royal Road Springfield, VA 22100 


\title{
Experimental Results From a 2kW Brayton Power Conversion Unit
}

\author{
David Hervol \\ Analex Corporation \\ Brook Park, Ohio 44142 \\ Lee Mason and Arthur Birchenough \\ National Aeronautics and Space Administration \\ Glenn Research Center \\ Cleveland, Ohio 44135
}

\begin{abstract}
This paper presents experimental test results from operation of a $2 \mathrm{kWe}$ Brayton power conversion unit. The Brayton converter was developed for a solar dynamic power system flight experiment planned for the Mir Space Station in 1997. The flight experiment was cancelled, but the converter was tested at Glenn Research Center as part of the Solar Dynamic Ground Test Demonstration system which included a solar concentrator, heat receiver, and space radiator. In preparation for the current testing, the heat receiver was removed and replaced with an electrical resistance heater, simulating the thermal input of a steady-state nuclear source. The converter was operated over a full range of thermal input power levels and rotor speeds to generate an overall performance map. The converter unit will serve as the centerpiece of a Nuclear Electric Propulsion Testbed at Glenn. Future potential uses for the Testbed include high voltage electrical controller development, integrated electric thruster testing and advanced radiator demonstration testing to help guide high power Brayton technology development for NEP.
\end{abstract}

\section{INTRODUCTION}

Closed Brayton cycle conversion technology has been identified as an excellent candidate for Nuclear Electric Propulsion (NEP) power conversion systems (Mason, 2001) (Mason et al., 2002). Advantages include high efficiency, long life, and high power density for power levels from about $10 \mathrm{kWe}$ to $1 \mathrm{MWe}$, and beyond. An additional benefit for Brayton is the potential for the alternator to deliver very high voltage as required by the electric thrusters, minimizing the mass and power losses associated with power management and distribution (PMAD).

In order to accelerate Brayton technology development for NEP, Glenn Research Center (GRC) has initiated a low power, NEP Testbed activity which utilizes an existing $2 \mathrm{kWe}$ Brayton Power Conversion Unit (PCU) from previous solar dynamic technology efforts (Shaltens, Mason, 1996, 1999). The PCU includes a turboalternator, recuperator, and gas cooler connected by gas ducts. The rotating assembly is supported by gas foil bearings and consists of a turbine, compressor, thrust rotor, and alternator on a single shaft as shown in figure 1. The completed turboalternator unit is shown in figure 2. The Brayton PCU will serve as the centerpiece of the NEP Testbed allowing future investigations of operational control methods, higher voltage PMAD, electric thruster interactions, and advanced radiators.

The existing $2 \mathrm{kWe}$ Brayton PCU was modified by removing the original solar dynamic heat receiver and retrofitting an electrical resistance heater to simulate the thermal input of a steady-state nuclear source. A series of tests were performed between June and August of 2002 that resulted in a total PCU operational time of 23.7 hours. An initial test sequence on June 17 determined that the reconfigured unit was fully operational. Ensuing tests provided the operational data needed to characterize PCU performance over its intended operating range. 


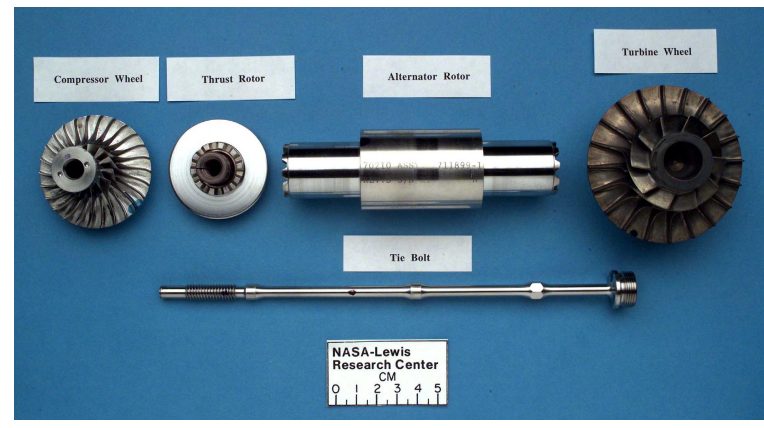

FIGURE 1. Turboalternator Rotating Assembly.

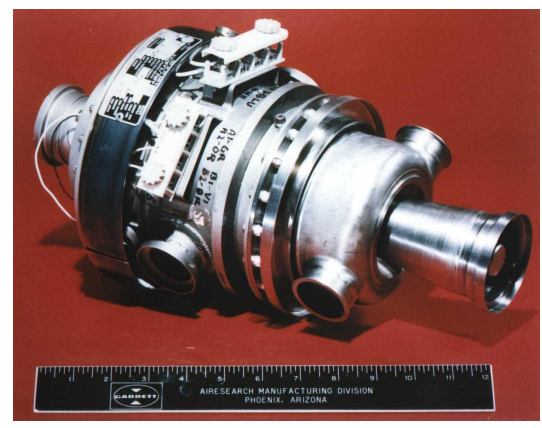

FIGURE 2. Turboalternator Unit.

\section{TEST SETUP}

The testing was performed in Vacuum Facility 6 (VF6) of building 301 at the NASA Glenn Research Center in Cleveland, Ohio. The overall test setup is shown in figure 3. The PCU is contained in the 3 meter test port at VF6. All electrical, instrumentation, and fluid connections are provided to the unit via tank wall feedthroughs. The three instrumentation racks on the right hand side of figure 3 house the PMAD, data acquisition, and test support equipment control electronics. Additional equipment supporting the Testbed operation includes the alternator test rig, gas charging cart, gas heater power supply, and PCU chiller.

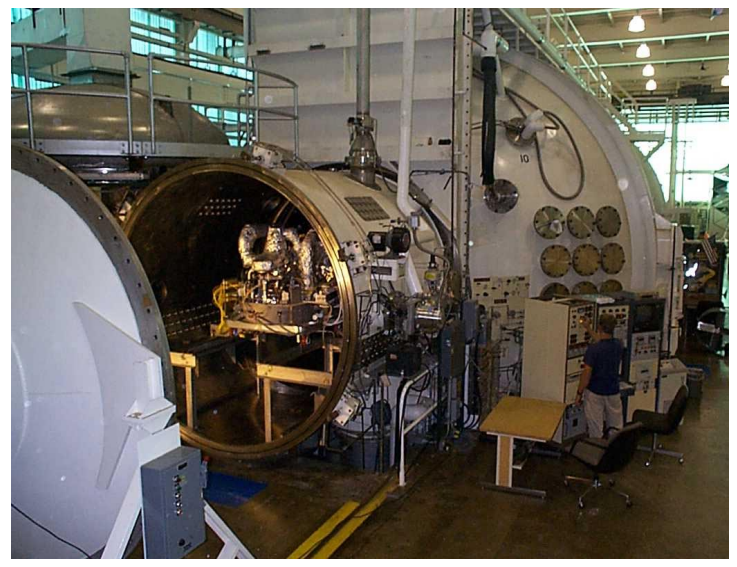

FIGURE 3. Brayton Testbed at GRC Vacuum Facility 6.

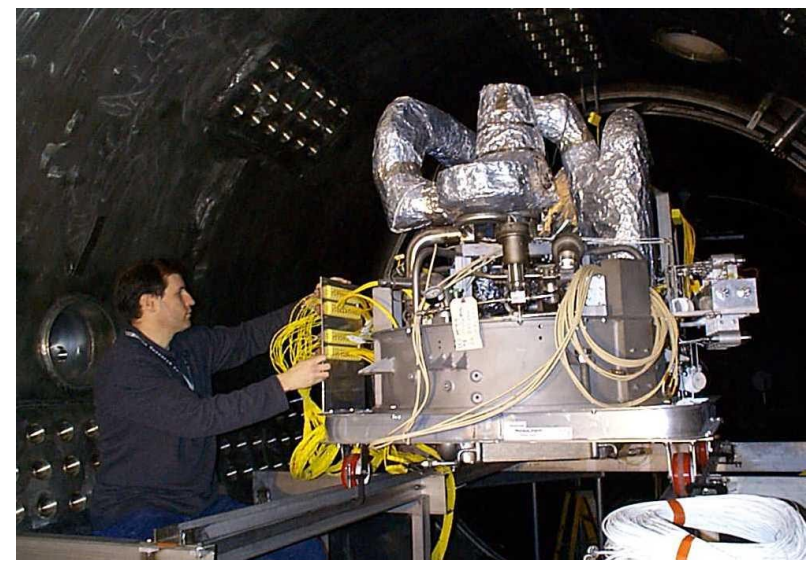

FIGURE 4. Brayton Power Conversion Unit.

Figure 4 shows the Brayton PCU as installed in the VF6 test port. The PCU produces AC power which is rectified to $120 \mathrm{~V}$ DC power by the PMAD unit. Test instrumentation includes 32 type $\mathrm{K}$ thermocouples, 8 pressure transducers, alternator voltage and current, DC load voltage and current, coolant flow rate, rotor speed, and heater electrical power. The entire PCU is covered in Multi-Foil Insulation (MFI) and operates in a rough vacuum environment $\left(\sim 1 \times 10^{-3}\right.$ torr $)$ to minimize heat transfer to the environment.

\section{Gas Heater}

The PCU gas heater consists of three resistive elements in series that are inserted into a shell and tube heat exchanger. The Si-C resistor elements are capable of withstanding sustained temperatures up to $1923 \mathrm{~K}$. These heating elements do not come into contact with the working fluid and heat the inner surface of the heater exclusively by radiation. This shell and tube heater is covered with MFI to minimize heat loss. The only area not covered with 
this insulation is where the electrical leads are attached. The gas heater assembly is shown in figure 5 before MFI was applied.

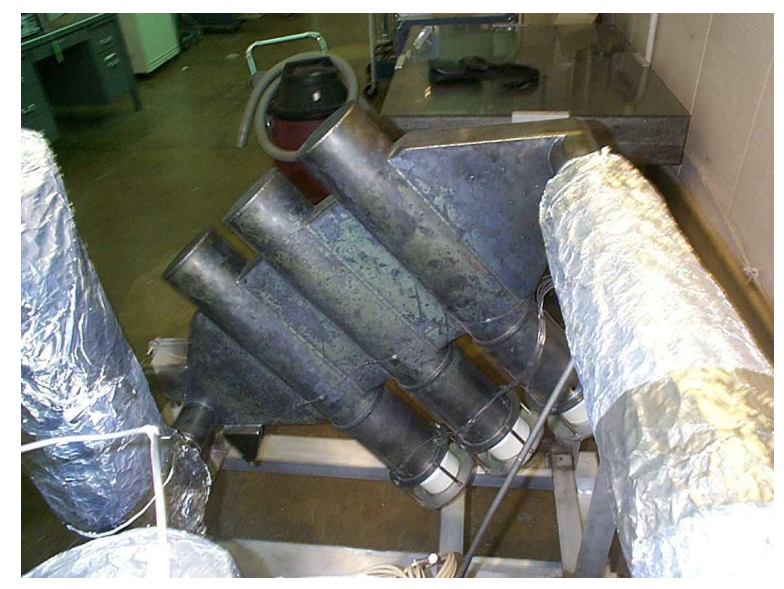

FIGURE 5. Gas Heater Assembly Before Insulation.

The electrical heater has a dedicated $480 \mathrm{~V}$ power supply that isolates it electrically from the remainder of the test equipment. The heater utilizes an industrial style Proportional-Integral-Derivative (PID) controller providing constant power to the resistive elements as specified by the test operator.

\section{Power Management and Distribution}

The PMAD electrical control system performs the functions of alternator output voltage rectification and regulation, rotor speed control, and PCU startup. The control system operates autonomously except for operator commands to begin and end motor starting. An inverter power supply provides electrical input to the alternator for startup motoring. The PMAD control system also provides redundant and automatic overspeed shutdown protection for the turboalternator.

The Brayton PCU includes a 3 phase permanent magnet alternator (Mason, Shaltens, 1997) that produces an output voltage proportional to the alternator speed, and inversely proportional to the applied load. The output voltage is rectified with a 3 phase full wave bridge, and then filtered to provide a smooth DC output of nominally $120 \mathrm{~V}$. At light loads the speed of the alternator is reduced to keep the output of the rectifier from exceeding $120 \mathrm{~V}$. At higher loads the alternator output drops to about $100 \mathrm{~V}$, and a boost converter circuit is used to increase the output of the rectifier back to $120 \mathrm{~V}$.

The electrical load on the alternator is controlled to regulate the rotational speed. If the load torque is equal to the torque supplied by the rotor, the speed will be constant. Increasing the alternator loading decreases the speed, and decreasing the alternator loading increases the speed. This technique is called parasitic load speed control. The amount of parasitic load applied to the machine is controlled, based on the speed setpoint specified by the test operator. The power in the parasitic load is then dissipated as waste heat. Power measurements were collected using a commercial $\mathrm{AC}$ power meter.

The design and assembly of the PMAD electronics rack was completed in-house at GRC. The alternator test rig (ATR) provided a critical tool in developing the overall electrical design and verifying the functionality. The ATR includes an air-driven turbine attached to a permanent magnet alternator which duplicates the PCU alternator's electrical characteristics to assist in troubleshooting of the PMAD rack without subjecting the PCU to unnecessary risk. 


\section{PCU Chiller}

Waste heat is removed from the PCU working fluid by the gas cooler and rejected into a 50\% ethylene glycol 50\% water mixture. A commercial chiller located in the test facility basement provided the final system coolant heat rejection. The chiller provides coolant flow rates of approximately 3 gallons per minute at a controlled setpoint of $273 \mathrm{~K}$ for heat loads up to about $4.5 \mathrm{kWt}$. The coolant supply temperature is the major influence on compressor inlet gas temperature. At higher heat loads, the coolant supply temperature and compressor inlet temperature experienced modest increases of 5 to $15 \mathrm{~K}$.

\section{Data Acquisition and Control}

Test data was acquired using a commercial datalogger connected to a desktop computer. The computer software performed real time calculations of heat input and heat rejected by the PCU, cycle efficiency, compressor and turbine efficiencies, recuperator effectiveness and mass flow rate. A Graphical User Interface (GUI) was provided showing all pressures, temperatures, power levels, voltages, currents, flow rates, and calculated values, as shown in figure 6 . Test data was concurrently saved to data files for post processing.

\section{8/22/2002 2:45:01 PM}

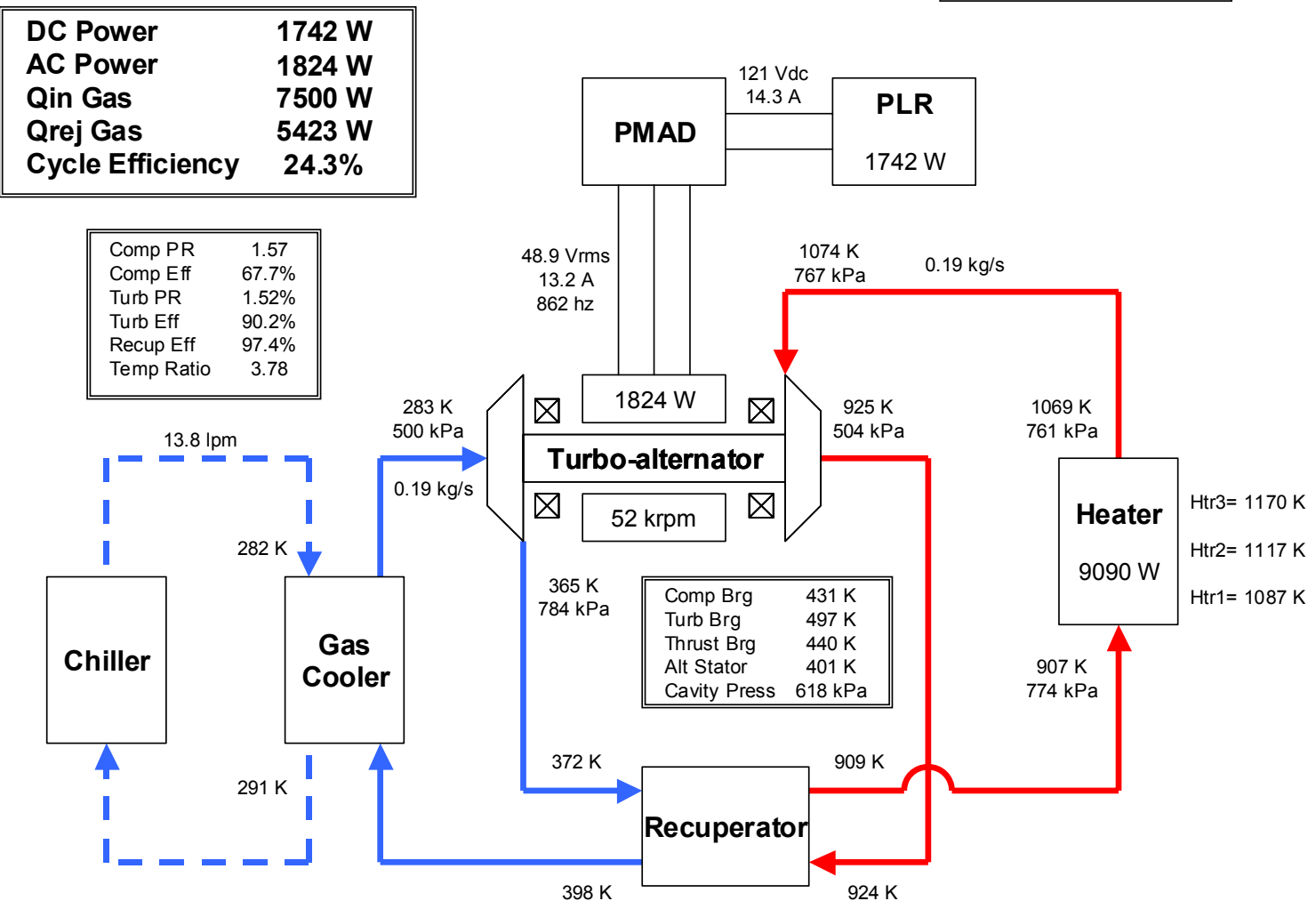

FIGURE 6. Graphical User Interface.

A second electronics rack houses operator interface control panels for the gas heater power supply, PCU chiller, and PCU bypass valves. The bypass valves are provided to isolate the compressor and turbine gas flow paths during alternator motoring, allowing faster and more efficient startups. 


\section{PCU Gas Charging Cart}

A gas charging system provides the capability to fill and maintain the working fluid charge. The Brayton PCU uses a $37 \%$ molar helium $63 \%$ molar xenon gas mixture working fluid, selected to optimize overall cycle efficiency. The mixture has a molecular weight of 83.8. Initially, the PCU was charged to $260 \mathrm{kPa}$ turbine inlet pressure for the June 17 initial test run. The inlet pressure reached $530 \mathrm{kPa}$ at $51000 \mathrm{rpm}$. It was decided to increase the initial charge pressure to allow for a higher system power capability. The unit was pre-charged to $330 \mathrm{kPa}$ for the June 24 test. The turbine inlet pressure reached $743 \mathrm{kPa}$ at $52000 \mathrm{rpm}$ during this run. This pre-run charge pressure was maintained on all subsequent tests.

\section{TEST MATRIX}

There are two primary variables used in operating the Brayton PCU: heater input power and rotor speed. The PCU was operated at 9 different heater power levels and 6 different rotor speeds resulting in 21 unique steady-state test points.

The general operating procedure included heating the gas to about $475 \mathrm{~K}$, and then motoring the alternator to circulate the gas until thermal conditions were suitable to sustain the thermodynamic cycle, allowing switchover to generate mode. The average alternator motoring time to achieve self-sufficient operation was about 10 minutes. After startup, heater power level and rotor speed setpoints were selected by the operator to achieve a particular test point. Test points were declared when steady state operation of the PCU was achieved, defined as less than $1 \mathrm{~K}$ change in the turbine inlet temperature over a 5 minute period. Regulated DC Voltage was maintained at $120 \mathrm{~V}$ for all of the tested heater power level and rotor speed combinations.

\section{TEST RESULTS}

The PCU was started and stopped a total 20 times. A total of 14 alternator motoring tests were used to troubleshoot the startup motoring operation. The remaining 6 start/stop cycles were fully operational test runs providing results in accordance with the test matrix.

\section{Alternator Motoring tests}

The PCU motor was initially wired in accordance with drawings available from the Solar Dynamic configuration. During the initial starts, the motor would only move a portion of a revolution or not at all. Re-phasing the alternator and speed sensors, and electrically retarding the sensors $60^{\circ}$ appeared to correct the problem, but the alternator was actually running in reverse. This was first noticed as the temperatures in the PCU were increasing in the wrong direction during motor start. For example, the heater inlet was rising in temperature instead of dropping. The motor phases and angle sensors were rewired and a $60^{\circ}$ sensor advance was added to correct this problem. Correct motor operation was confirmed by the observing correct gas flow direction.

\section{Electrical Power Output}

After an initial series of tests that determined operational limits, PCU performance was fully characterized at 48000 $\mathrm{rpm}$ and $52000 \mathrm{rpm}$ for a variety of gas heater power levels. Cycle temperature ratio (turbine inlet divided by compressor inlet temperature) provides an effective dependent parameter for evaluating PCU and component performance. Figure 7 shows the linear relationship between AC power output and temperature ratio. Testing demonstrated a maximum steady-state AC power output of 1835 watts at a gas heater power of 9000 watts and a rotor speed of $52000 \mathrm{rpm}$. This equates to a net DC power output of 1750 watts, corresponding to a PMAD efficiency of $95 \%$. 


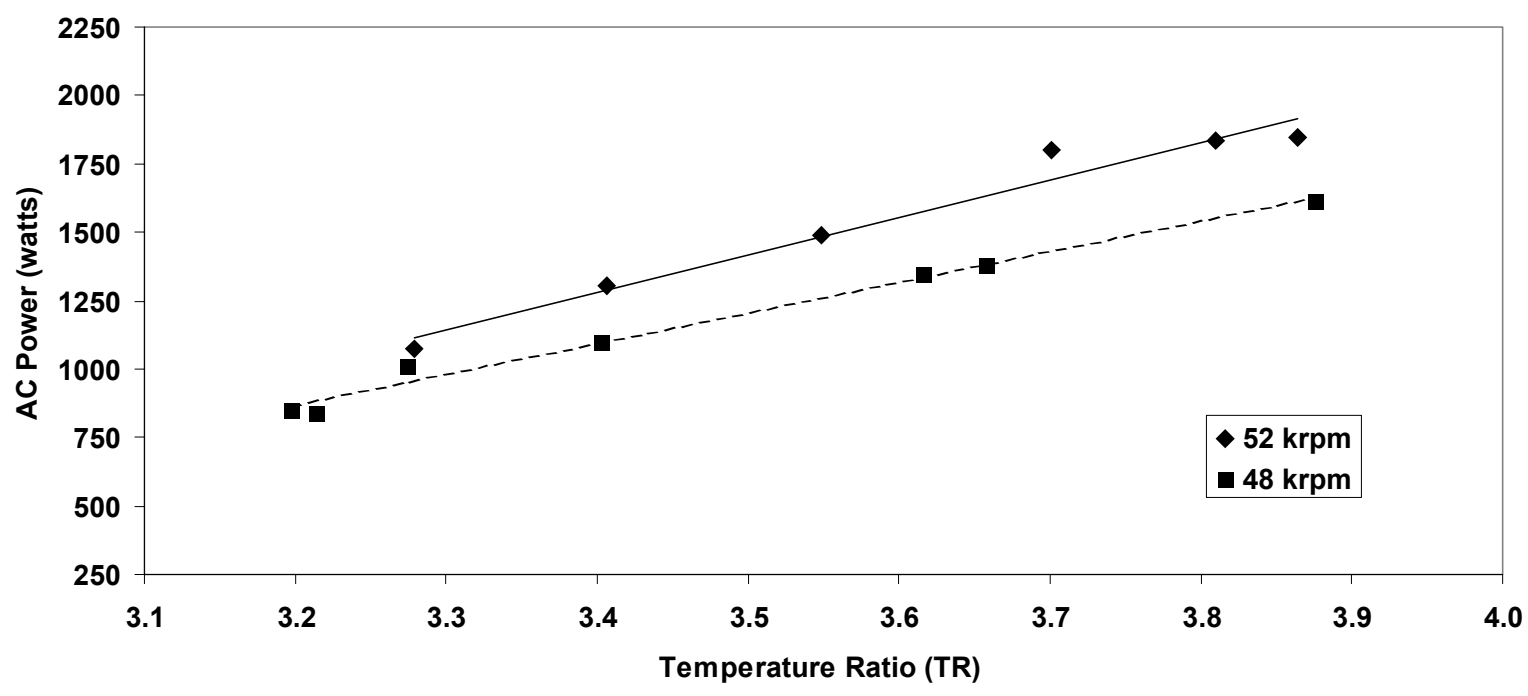

FIGURE 7. AC Power Output.

\section{Cycle Efficiency}

Figure 8 shows the relationship between cycle efficiency and temperature ratio for the 48000 and 52000 rpm rotor speed setpoints. Rotor speed has a negligible effect on cycle efficiency as indicated by the similarity of the two line fits. Testing demonstrated a maximum steady-state cycle efficiency of $24 \%$ at a gas electrical heater power of 9000 watts and a rotor speed of $52000 \mathrm{rpm}$.

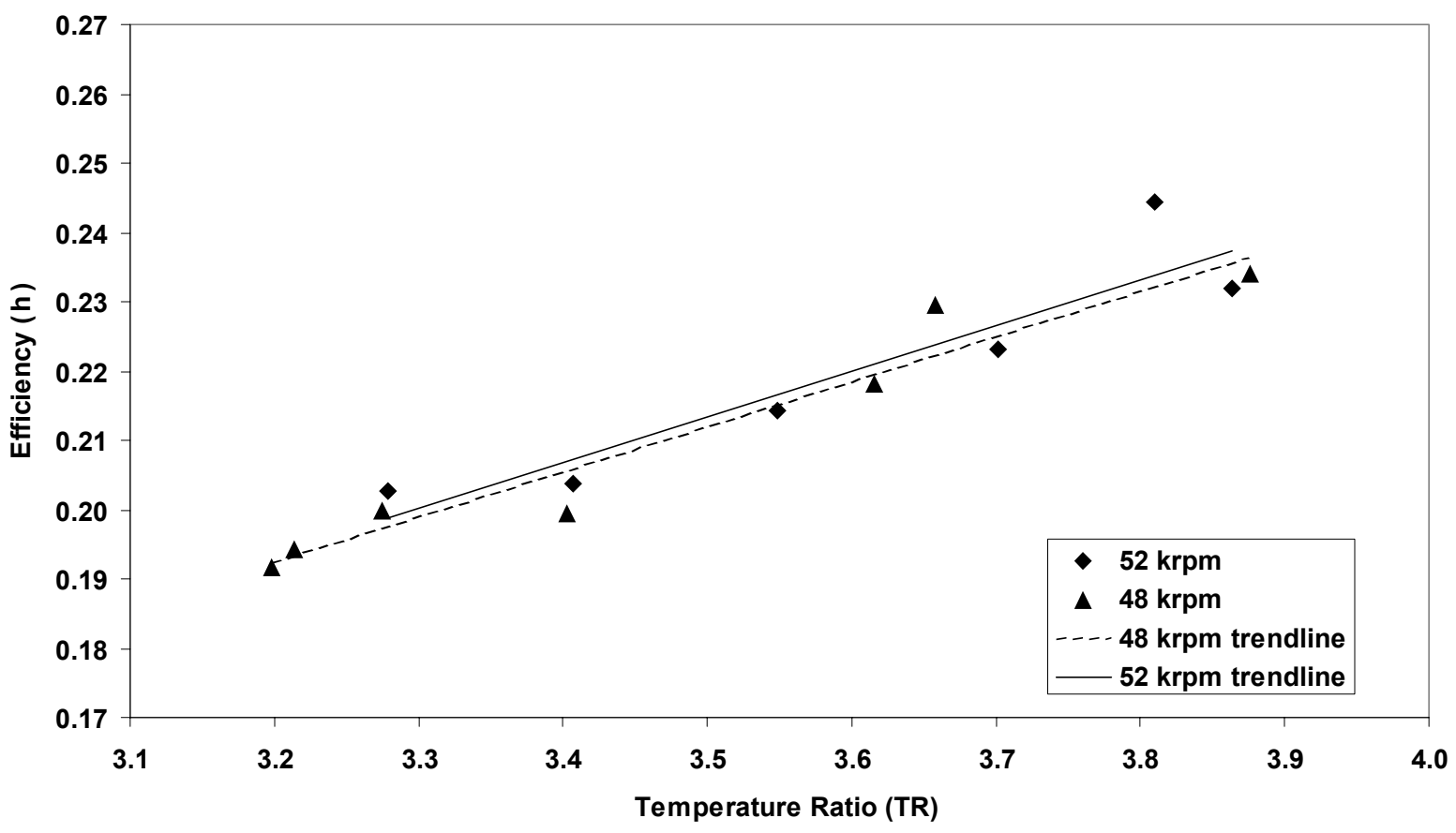

FIGURE 8. Cycle Efficiency. 
Pressure ratios and pressure loss fractions have a dramatic effect on cycle efficiency. At $52000 \mathrm{rpm}$, the compressor pressure ratio was about 1.57 and the turbine pressure ratio was about 1.52 . This corresponds to a pressure loss fraction of $97 \%$. Component gas pressure losses for the maximum power test point at $52000 \mathrm{rpm}$ were $0.8 \%$ for the heater, $1.4 \%$ for high pressure side of the recuperator, and $0.8 \%$ for the combined pressure loss through the low pressure side of the recuperator and gas cooler.

\section{Component Efficiencies}

Figure 9 shows the relationship of turbine and compressor efficiency, and recuperator effectiveness versus temperature ratio at $52000 \mathrm{rpm}$. As shown, turbine efficiency increases and compressor efficiency and recuperator effectiveness decrease with increasing temperature ratio. Testing obtained a maximum steady-state turbine efficiency of $96 \%$ and a maximum steady-state compressor efficiency of $70 \%$. The maximum steady-state recuperator effectiveness was $98 \%$.

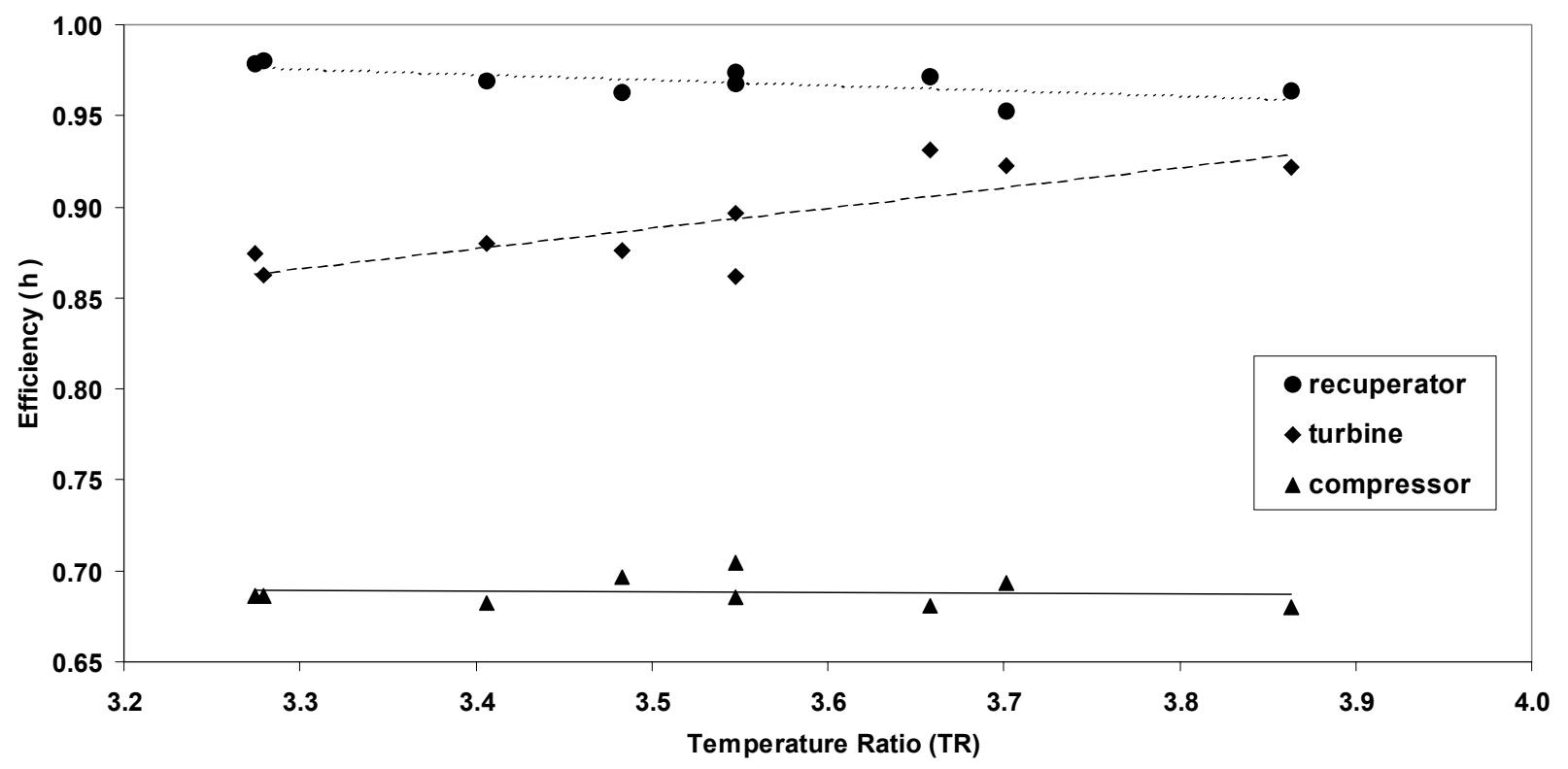

FIGURE 9. Turbine, Compressor Efficiency and Recuperator Effectiveness vs. Temperature Ratio at $52000 \mathrm{rpm}$.

\section{PCU Shutdown}

PCU shutdown is initiated by turning off the electrical heaters. There is enough residual thermal energy to continue operating the unit for approximately 30 minutes. After the measured power output has dropped to zero, the bypass valves are opened and the time for the unit to stop is measured. This measurement is called rolldown time which provides a useful parameter for assessing the health of the foil bearings. Rolldown times were consistently around 25 seconds, indicating that the foil bearings are still in good condition despite their long term storage following the Solar Dynamic testing and current operation during this series of tests.

\section{TESTING ISSUES}

Vacuum arcing occurred several times during startup of the electrical gas heater. This arcing tripped the circuit breaker in the $480 \mathrm{~V}$ heater power supply. No other systems were affected. Arcing only transpired during heater restart following a vacuum cooldown. Video of the heater during restart showed the arc initiating from near the electrical leads. Arcing did not occur when the chamber was re-pressurized between tests. After some investigation, it was determined that the unit was operating at an unfavorable combination of heater voltage and 
vacuum level that is susceptible to arcing. Measures are being pursued which should eliminate this phenomenon. The first measure will cover the electrical power leads with ceramic standoffs and seal them with high temperature ceramic putty. The second measure is to filter the heater power supply thus reducing the sharp current transients resulting from the waveform chopping used to control heater power.

\section{CONCLUSION}

The reconfigured Brayton PCU has been shown to operate efficiently and reliably in a vacuum environment. Rotor speed was dependably maintained at setpoint conditions and voltage was consistently regulated at $120 \mathrm{~V}$ DC over the entire range of speeds and heat inputs. Power output and cycle efficiency were characterized over the full heater input power and rotor speed range. The Brayton PCU is ready to provide power for follow-on testing in support of NEP technology development.

\section{REFERENCES}

Mason, L.S., "A Comparison of Brayton and Stirling Space Nuclear Power Systems for power Levels from 1 Kilowatt to 10 Megawatts,” NASA/TM-2001-210593, January 2001.

Mason, L.S., Shaltens, R.K., Dolce, J.L., and Cataldo, R.L., "Status of Brayton Cycle Power Conversion Development at NASA GRC,” NASA/TM-2002-211304, January 2002.

Mason, L.S. and Shaltens, R.K., "Experimental Data for Two Different Alternator Configurations in a Solar Brayton Power System,” NASA Technical Memorandum 107509, IECEC-97481, August 1, 1997.

Shaltens R.K. and Mason, L.S., Journal of Propulsion and Power 12, No. 5, 852-858 (1996).

Shaltens, R.K. and Mason, L.S., "800 Hours of Operational Experience From a 2 kWe Solar Dynamic System," NASA/TM-1999-208840, January 1999. 
Public reporting burden for this collection of information is estimated to average 1 hour per response, including the time for reviewing instructions, searching existing data sources, gathering and maintaining the data needed, and completing and reviewing the collection of information. Send comments regarding this burden estimate or any other aspect of this collection of information, including suggestions for reducing this burden, to Washington Headquarters Services, Directorate for Information Operations and Reports, 1215 Jefferson Davis Highway, Suite 1204, Arlington, VA 22202-4302, and to the Office of Management and Budget, Paperwork Reduction Project (0704-0188), Washington, DC 20503.

\begin{tabular}{|l|l|l|}
\hline 1. AGENCY USE ONLY (Leave blank) & $\begin{array}{c}\text { 2. REPORT DATE } \\
\text { January } 2003\end{array}$ & $\begin{array}{r}\text { 3. REPORT TYPE AND DATES COVERED } \\
\text { Technical Memorandum }\end{array}$ \\
\hline
\end{tabular}

4. TITLE AND SUBTITLE

5. FUNDING NUMBERS

Experimental Results From a 2kW Brayton Power Conversion Unit

6. AUTHOR(S)

WBS-22-800-90-01

David Hervol, Lee Mason, and Arthur Birchenough

7. PERFORMING ORGANIZATION NAME(S) AND ADDRESS(ES)

National Aeronautics and Space Administration

John H. Glenn Research Center at Lewis Field

Cleveland, Ohio 44135-3191

8. PERFORMING ORGANIZATION

REPORT NUMBER

E-13671

9. SPONSORING/MONITORING AGENCY NAME(S) AND ADDRESS(ES)

10. SPONSORING/MONITORING

AGENCY REPORT NUMBER

National Aeronautics and Space Administration

Washington, DC 20546-0001

NASA TM-2003-211999

\section{SUPPLEMENTARY NOTES}

Prepared for the Space Technology and Applications International Forum (STAIF-2003) cosponsored by the American Institute of Aeronautics and Astronautics and the University of New Mexico, Albuquerque, New Mexico,

February 2-6, 2003. David Hervol, Analex Corporation, Brook Park, Ohio 44142; Lee Mason and Arthur Birchenough, NASA Glenn Research Center. Responsible person, David Hervol, organization code 5490, 216-433-9624.

12a. DISTRIBUTION/AVAILABILITY STATEMENT

12b. DISTRIBUTION CODE

Unclassified - Unlimited

Subject Category: 20

Distribution: Nonstandard

Available electronically at http://gltrs.grc.nasa.gov

This publication is available from the NASA Center for AeroSpace Information, 301-621-0390.

13. ABSTRACT (Maximum 200 words)

This paper presents experimental test results from operation of a $2 \mathrm{kWe}$ Brayton power conversion unit. The Brayton converter was developed for a solar dynamic power system flight experiment planned for the Mir Space Station in 1997. The flight experiment was cancelled, but the converter was tested at Glenn Research Center as part of the Solar Dynamic Ground Test Demonstration system which included a solar concentrator, heat receiver, and space radiator. In preparation for the current testing, the heat receiver was removed and replaced with an electrical resistance heater, simulating the thermal input of a steady-state nuclear source. The converter was operated over a full range of thermal input power levels and rotor speeds to generate an overall performance map. The converter unit will serve as the centerpiece of a Nuclear Electric Propulsion Testbed at Glenn. Future potential uses for the Testbed include high voltage electrical controller development, integrated electric thruster testing and advanced radiator demonstration testing to help guide high power Brayton technology development for NEP.

14. SUBJECT TERMS

Nuclear electric power generation; Nuclear electric propulsion; Brayton cycle 15. NUMBER OF PAGES 14

17. SECURITY CLASSIFICATION OF REPORT

Unclassified

18. SECURITY CLASSIFICATION
OF THIS PAGE
Unclassified

Unclassified

19. SECURITY CLASSIFICATION
OF ABSTRACT
Unclassified

NSN 7540-01-280-5500
Standard Form 298 (Rev, 2-89)

Prescribed by ANSI Std. Z39-18 298-102 